\title{
Phthorimaea operculella (Zeller, 1873), First Record of an Invasive Pest in Hungary (Lepidoptera, Gelechiidae)
}

\author{
D. HORVÁTH ${ }^{1 *}$, I. FAZEKAS ${ }^{2}$ and S. KESZTHELYI ${ }^{3}$ \\ ${ }^{1}$ Department of Entomology, Faculty of Horticulture Science, Szent István University, \\ H-1118 Budapest, Villányi út 29-43, Hungary \\ ${ }^{2}$ Regiograf Institute, H-7625 Pécs, Magaslati út 24, Hungary \\ ${ }^{3}$ Department of Plant Production and Plant Protection, Faculty of Agricultural and Environmental Sciences, \\ Kaposvár University, H-7400 Kaposvár, Guba S. u. 40, Hungary
}

(Received: 28 July 2016; accepted: 3 November 2016)

\begin{abstract}
The invasive gelechiid moth, potato tuberworm Phthorimaea operculella (Zeller, 1873) was first recorded in Hungary (Komló, Baranya County) and Northern Croatia (Lug, Osijek-Baranja County) in December 2015. This quarantine species has not been reported from Hungary so far and it was known in Croatia only from the coastal region. The occurrence of Ph. operculella in the Carpathian basin is of great concern as this invader is able to cause negative impacts on the Hungarian potato cultivation. This occurrence of the species is one of the northernmost data in Europe so far.
\end{abstract}

Keywords: Gelechiidae, Phthorimaea operculella, potato tuberworm, first record, Hungary.

The potato tuberworm Phthorimaea operculella (Zeller, 1873), also known as potato tuber moth or tobacco splitworm, is an oligophagous pest of crops belonging to the family Solanaceae such as Solanum tuberosum L., S. lycopersicum L., S. melongena L., S. dulcamara L., Nicotiana tabacum L., N. glauca Graham. According to Povolný (2002) the larva has been recorded from Solanum nigrum L., S. villosum Mill., Datura stramonium L., Physalis viscosa L., Hyoscyamus albus L. and H. niger L.

Its main host plant is potato (Reichart, 1970; Golizadeh and Esmaeili, 2012). Ph. operculella affects the yield of potatoes, reduces quality of the product, and increases the risk of infection by plant pathogens. The common name, potato tuberworm, is referring to its damaging larval stage. Two to thirteen generations can develop in a year depending on climatic conditions. (Mukherjee, 1949; Al-Ali et al., 1975). There are usually two generations per year in temperate climates (Trivedi and Rajagopal, 1992). Eggs, larvae and pupae of potato tuberworm can potentially survive in volunteer potatoes or in the soil after harvest. Potato tuberworm is known to overwinter in the soil as pupae (Czencz, 1997).

$P h$. operculella is endemic species in western part of South-America (Povolný, 1964). It was a neotropical fauna element, which has become a cosmopolitan pest since

* Corresponding author; e-mail: horvathdow@gmail.com 
more than one hundred years (Huemer and Karsholt, 2010). In Europe it is mainly restricted to the southern parts. This pest occurs in most areas where potatoes or other solanaceous plants are grown. It was first recorded in California in 1856 (Rondon, 2010). However, it was not a major concern for growers in the Pacific Northwest until 2002, when severe potato tuberworm damage was documented in a field near Hermiston, Oregon (Rondon et al., 2013). It occurs widely in Africa, Asia, Europe, Americas and Oceania (Trivedi and Rajagopal, 1992; Vargas et al., 2004; Kroschel et al., 2013). This pest has been reported in tropical, subtropical, and Mediterranean zones (Trivedi and Rajagopal, 1992; Golizadeh and Esmaeili, 2012). The Hungarian introduction of this moth had been already predicted in 1926 (Jablonowski, 1926). This dangerous, quarantine pest has not been introduced in Hungary yet (CABI/EPPO, 2012; EPPO, 2014).

\section{Materials and Methods}

In the middle of October 2015, a population of an unknown Lepidoptera larvae on pile of stored potato was found in Lug, Croatia (45'39'55.9'N 18³9'49.9'"E), 17 kilometres far from Hungarian border. More than 4 tonnes of stored potato was destroyed by the larvae. Infected potatoes were detected later in a market of Komló, Hungary on the 16th of December 2015, about 60 kilometres far from the Croatian occurrence. The exact locality of the production of these potatoes is not known, but as far as we know the producer is farming in Baranya County, Hungary. Collected samples were placed in

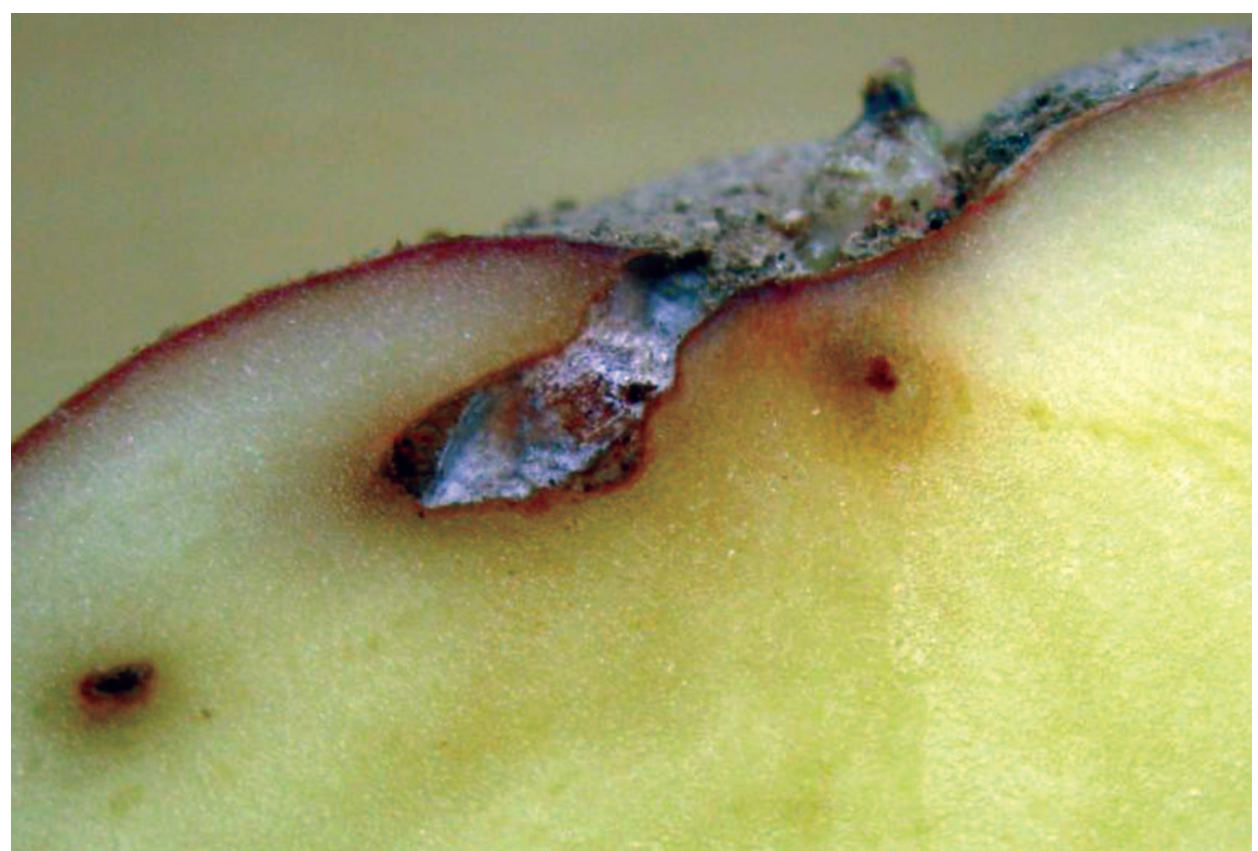

Fig. 1. Larvae tunnel of Phthorimaea operculella into potato tuber (photo: D. Horváth) 


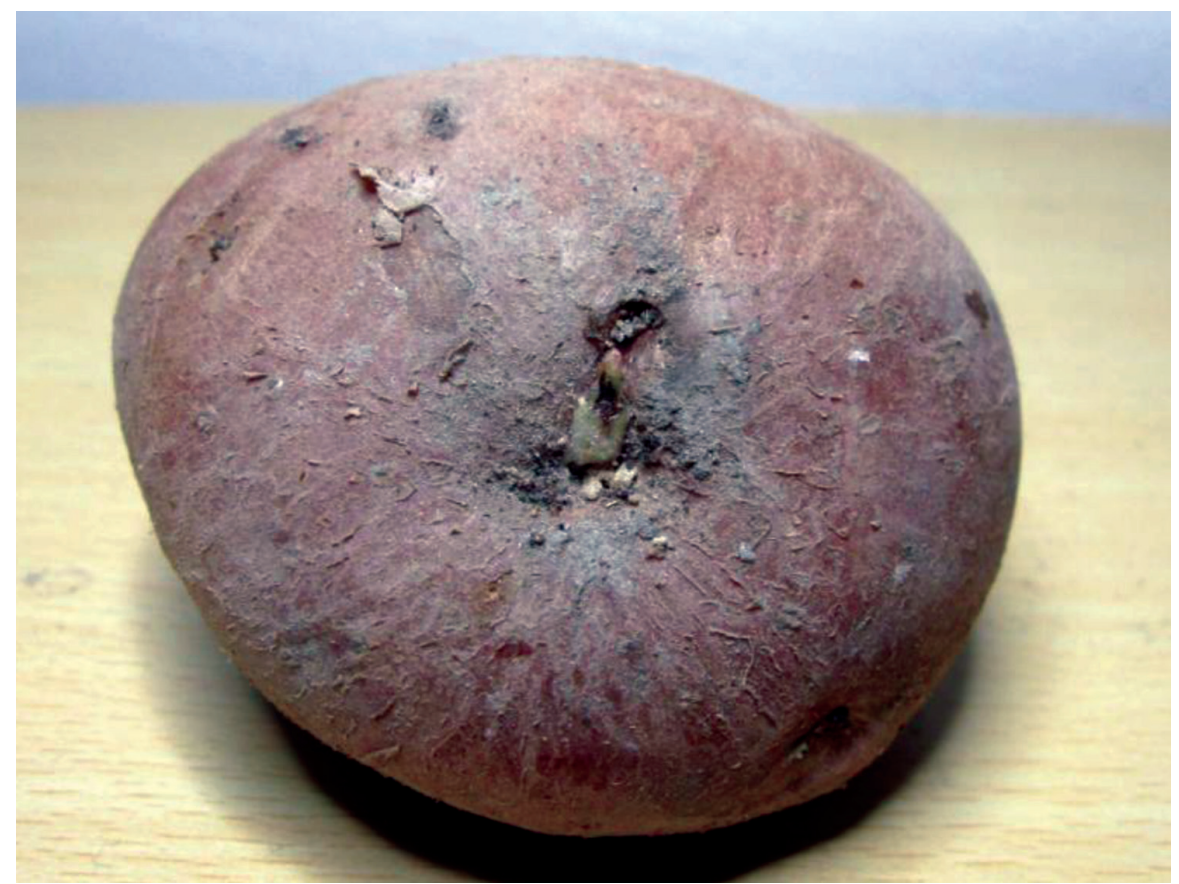

Fig. 2. Faeces, mastication extracts of Phthorimaea operculella at exit holes onto potato tuber (photo: D. Horváth)

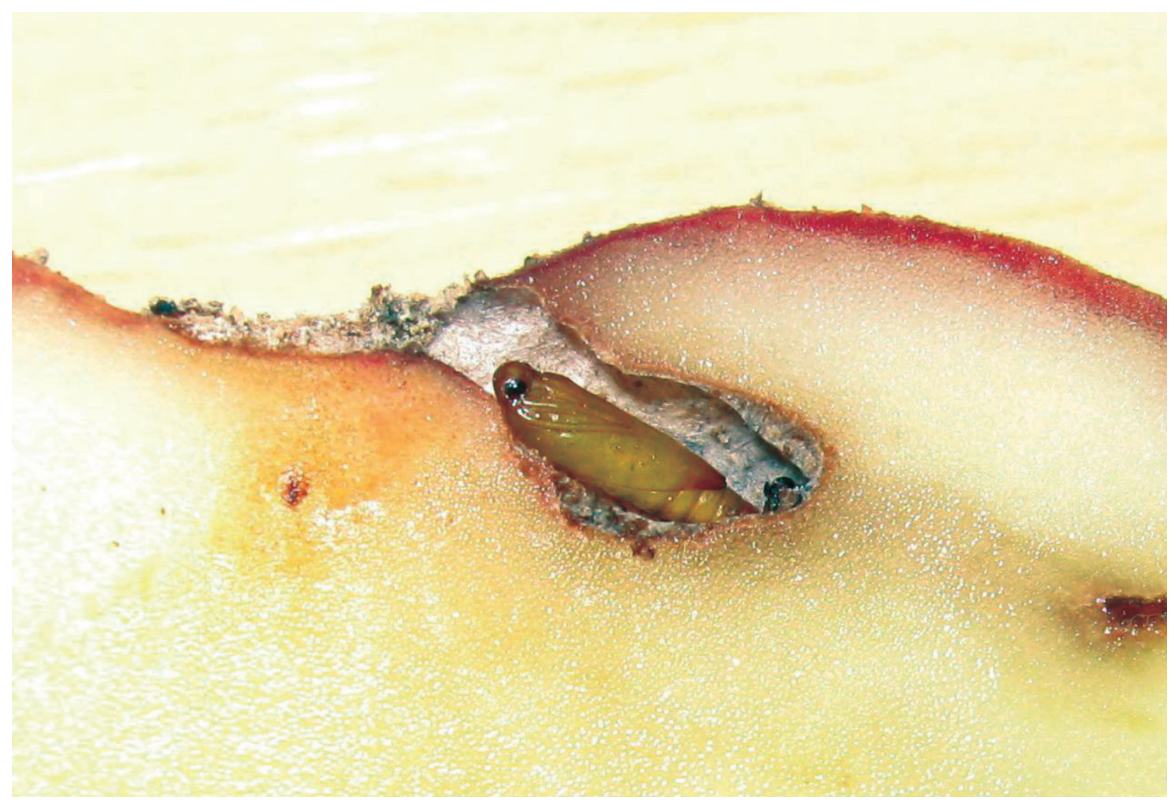

Fig. 3. Pupa of Phthorimaea operculella into larvae tunnel (photo: D. Horváth) 


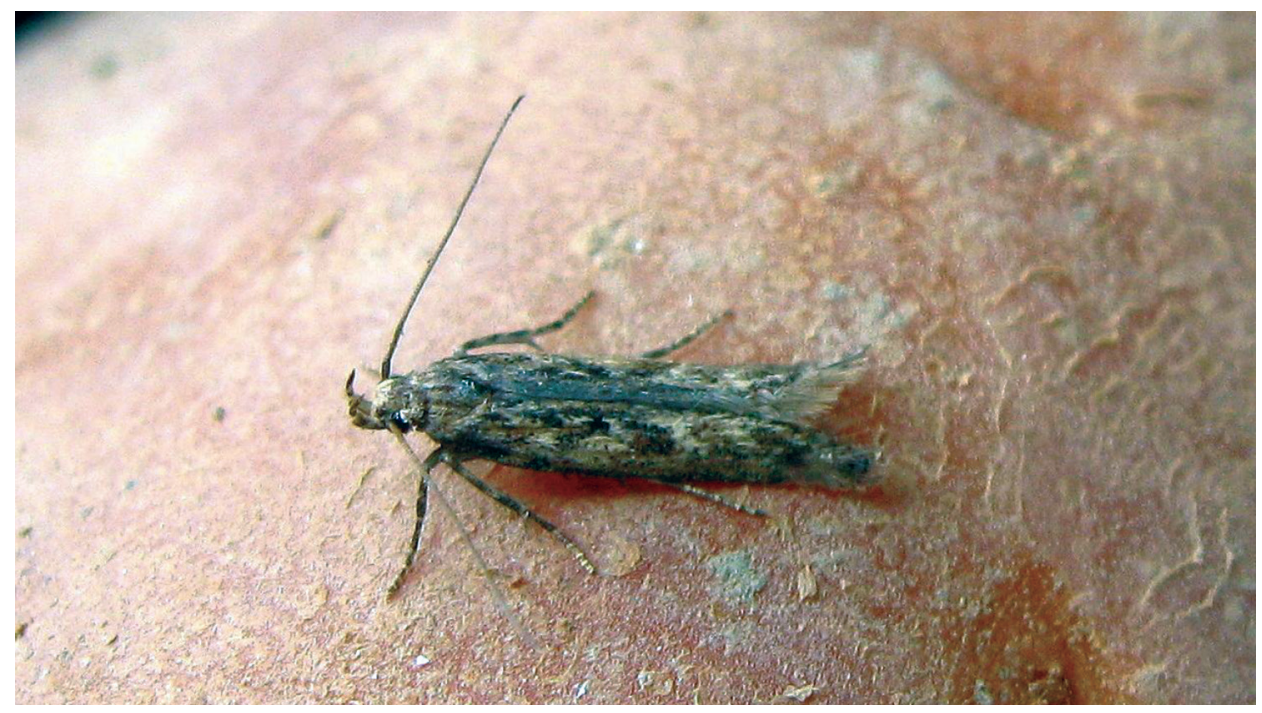

Fig. 4. Newly hatched adult of Phthorimaea operculella (photo: D. Horváth)
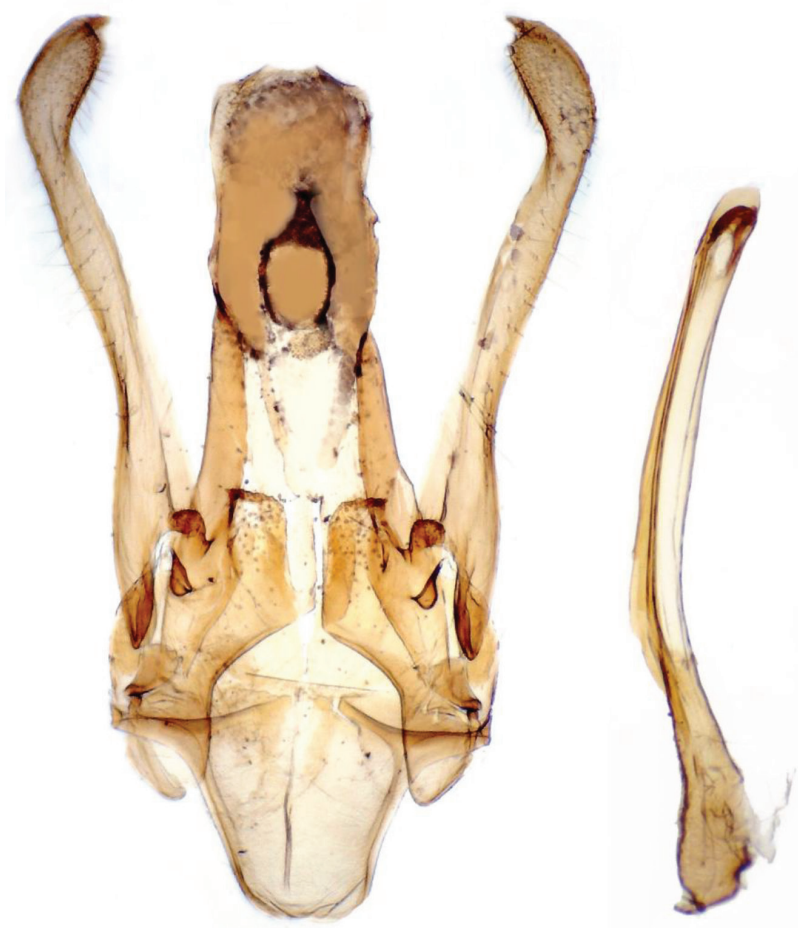

Fig. 5. Male genitalia of Phthorimaea operculella: Hungary, Komló, leg. et gen. prep. I. Fazekas, No. 3440 (amplification 20x) (microphoto: I. Fazekas) 
isolators in the laboratory of Regiograf Institute. After the hatching the genitalia of raised specimens were cleared and microphotos were made (Figs 5,6). The exact determination of the species was based on the genitalia that confirmed the specimens belong to the Ph. operculella species. The specimens were placed in the personal collection of Imre Fazekas and the insect collection of the Department of Entomology, Szent István University, Budapest.

\section{Results}

\section{Illustration of damage on potato tuber}

The parameters of the differed samples were the following: Hungarian sample: 8 pieces of potato tuber $(960 \mathrm{~g})$; Croatian sample: 17 pieces of potato tuber $(2100 \mathrm{~g}) .7$ pupae and several pellicles have been found in Hungarian samples. 3 pupae, several pellicles and a perished imago have been observed in Croatian samples. Larvae were fed on potato tubers in storage. Typical damage results from larvae were boring tunnels in tubers (Fig.1). Larvae depositing their excreta make tubers unfit for consumption. Faeces and mastication extracts of larvae can be observed on the surface of the attacked potato tuber (Fig. 2). The damaging larvae were pupated in tunnels (Fig. 3). Potato tuber eyes become pink due to deposition of silk and excrement by potato tuberworm infestation. Eventually, the imagoes were hatched in isolators (Fig. 4). The hatching of the 2 female 5 male moths took 2 to 7 days in room temperature. Each identified individual was originated from Hungarian samples.

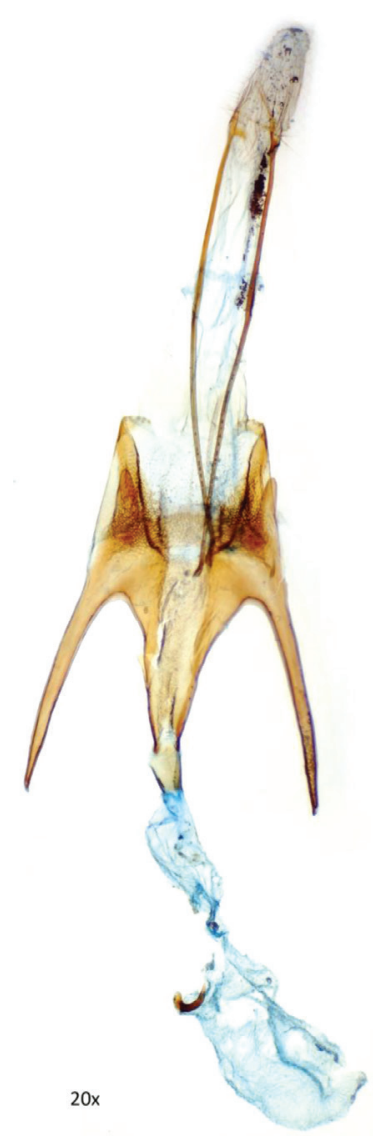

Fig. 6. Female genitalia of Phthorimaea operculella: Croatia, Lug, leg. D. Horváth, gen. prep. I. Fazekas, No. 3441 (microphoto: I. Fazekas)

\section{Discussion}

The potato tuberworm, Phthorimaea operculella (Zeller, 1873) (Lepidoptera: Gelechiidae) has not been reported from Hungary (CABI/EPPO 2012, EPPO 2014) so far.

Our data are one of the northernmost occurrences of the species in Europe. The two reported occurrences are in two different countries, but relatively close to each other (about $60 \mathrm{~km}$ ) that can mean, the species have widespread and stable population in the region. Nevertheless, further northward expansion of this pest can be assumed based on the experienced climatic trends (Kroschel et al. 2013). Besides, the occurrence of Ph. operculella in the Carpathian basin is of great concern as this invader represents an important threat for the Hungarian potato cultivation. 


\section{Acknowledgment}

We would like to say thanks to Teodóra Fór for the Croatian report and data of the species and for the language review of the manuscript.

\section{Literature}

Al-Ali, A. S., Al-Neamy, I. K. and Abbas, S. A. (1975): Observations on the biology of the potato tuber moth Phthorimaea operculella (Zeller) (Lepidoptera: Gelechiidae) in Iraq. Zeitschrift für Angewandte Entomologie 79, 345-351.

CABI/EPPO (2012): Phthorimaea operculella. [Distribution map]. Distribution Maps of Plant Pests, No.June. Wallingford, UK: CABI, Map 10 (2nd revision). http://www.cabi.org/isc/abstract/20123252643

Czencz, K. (1997): A burgonya kártevői. (Pests of the Potato). In: M. Glits, J. Horváth, G. Kuroli and I. Petróczi (eds): Növényvédelem pp. 202-207. Mezőgazda Kiadó, Budapest (in Hungarian).

EPPO (2014): PQR database. Paris, France: European and Mediterranean Plant Protection Organization. <http:// www.eppo.int/DATABASES/pqr/pqr.htm>http://www.eppo.int/DATABASES/pqr/pqr.htm

Golizadeh, A. and Esmaeili, N. (2012): Comparative life history and fecundity of Phthorimaea operculella (Lepidoptera: Gelechiidae) on leaves and tubers of different potato cultivars. J. Econ. Entomol. 105, 1809-1815. doi: 10.1603/EC12144.

Huemer, P. and Karsholt, O. (2010): Gelechiidae II. (Gelechiinae: Gnorimoschemini). In: P. Huemer, O. Karsholt and M. Nuss (eds): Microlepidoptera of Europe 6. Apollo Books, Stenstrup, pp. 1-586.

Jablonowski, J. (1926): A kolorádói burgonyabogár, a burgonyamoly és egyéb burgonyabetegségek (The Colorado Potato Beetle, the Potato Tuberworm and other potato pests). Rovartani Közlemények 1, 96-97. (in Hungarian).

Kroschel, J., Sporleder, M., Tonnang, H. E. Z., Juarez, H., Carhuapoma, P., Gonzales, J. C. and Simon, R. (2013): Predicting climate-change-caused changes in global temperature on potato tuber moth Phthorimaea operculella (Zeller) distribution and abundance using phenology modeling and GIS mapping. Agricultural and Forest Meteorology 170, 228-241. doi: 10.1016/j.agrformet.2012.06.017

Mukherjee, A. K. (1949): Life-history and bionomics of potato moth (Gnorimoschema operculella Zell.) at Allahabad (U.P.) together with some notes on the external morphology of the immature stages. J. Zoological Society of India 1, 57-67.

Povolný, D. (1964): Gnorimoschemini trib. nov. eine neue Tribus der Familie Gelechiidae nebst Bemerkungen zu ihrer Taxonomie (Lepidoptera). Časopis Československé Společnosti Entomologické 61, 330-359. [in German]

Povolný, D. (2002): Iconographia tribus Gnorimoschemini (Lepidoptera, Gelechiidae) Regionis Palaearcticae. František Slamka, Bratislava, 110 p. $16+87$ pls.

Reichart, G. (1970): A burgonyamoly (The Potato Tuberworm). In: M. Sebestyén and M. Váradi (eds): Növényvédelmi Karantén Kézikönyv. MÉM Növényvédelmi Szolgálat Kiadványa, 195-200. Budapest (in Hungarian).

Rondon, S. I. (2010): The potato tuberworm: A literature review of its biology, ecology, and control. American J. Potato Research 87, 149-166. doi: 10.1007/s12230-009-9123-X

Rondon, S. I., Brown, C. R. and Marchosky, R. (2013): Screening for resistance of potato lines to the potato tuberworm, Phthorimaea operculella (Zeller) (Lepidoptera: Gelechiidae). American J. Potato Research 90, 71-82. doi: 10.1603/029.102.0432

Trivedi, T. P. and Rajagopal, D. (1992): Distribution, biology, ecology and management of potato tuber moth, Phthorimaea operculella (Zeller) (Lepidoptera: Gelechiidae): a review. International J. Pest Management 38, 279-285. doi: 10.1080/09670879209371709

Vargas, B., Rubio, S. and López-Avila, A. (2004): Estudios de hábitos y comportamiento de la polilla guatemalteca Tecia solanivora (Lepidoptera: Gelechiidae) en papa almacenada. Revista Colombiana de Entomología 30, 211-217. (in Spanish with English summary). 